\title{
EDUSERV - THE EDUCATION SERVICE OF EUROSDR: SHARING EXPERIENCE FOR CAPACITY BUILDING
}

\author{
D. Fritsch ${ }^{\mathrm{a}}$, K. Mooney ${ }^{\mathrm{b}}$, A. Oestman ${ }^{\mathrm{c}}$ \\ ${ }^{a}$ Ifp, Institute for Photogrammetry, Univ. of Stuttgart, Geschwister-Scholl-Str. 24B, D-70174 Stuttgart, Germany \\ dieter.fritsch@ifp.uni-stuttgart.de \\ ${ }^{\mathrm{b}}$ DIT, Dublin Institute of Technology, Department of Spatial Information Science, Bolton Street, Dublin 1, Ireland \\ kevin.mooney@dit.ie \\ ${ }^{\mathrm{c}}$ Division of Geomatics, University of Gaevle, SE-80176 Gaevle, Sweden \\ anders.ostman@swedesurvey.se
}

Commission VI, Congress Theme Session

KEY WORDS: Internet/Web, Education, Exchange, Learning, International

\begin{abstract}
This paper describes EduServ, the Education Service of EuroSDR - a European spatial data research organisation whose aim is to address the research needs of spatial data provision in Europe. With a current membership coming from seventeen European countries and a strong working relationship with related European organisations, EuroSDR has amassed considerable experience in addressing the extent and nature of this need. In order to facilitate the transfer of outcomes of EuroSDR research activities to the user domain, e.g. to key personnel in geographic information (GI) production organisations and industry, EuroSDR commenced this annual series of elearning courses in 2002. The Internet courses are preceded by a seminar at which participants meet tutors and receive guidelines for following the courses from their own locations. Delivery of the two-week courses requires an acceptable level of Internet connectivity, which exists in most member countries. EuroSDR is aware, however, that should such courses be shared internationally, other forms of communication will need to be addressed, such as satellite broadcasting. This would require effective collaboration with related organisations with experience with this means of communication. EduServ courses are offered in two successive years. During the courses, participants enjoy access to course tutors with a 24-hour response to queries guaranteed. Thereafter, course material for these courses is made available online. EuroSDR continues to work with past course tutors to ensure that this valuable resource is maintained as an effective and sustainable archive. This paper is aimed at sharing EuroSDR's experience in distance education with the wider scientific community with a view to its applicability to a global audience, whereby instead of sharing expertise within the GI community in Europe, European mapping agencies can share their knowledge and experience with the international GI community.
\end{abstract}

\section{INTRODUCTION}

\subsection{General Developments in ICT}

Internet technologies fascinate people of all age groups. The three buzzwords of everyday life are "always on, anywhere and anyplace". Mobile devices have become more and more powerful - they allow for learning-with-fun, creativity at any time and at any place, and public understanding of complex issues.

Most probably, within the next five years we will use mobile devices with built-in Inertial Navigation sensors and general GNSS receivers which are compatible with all systems in use: GPS, Galileo, Glonass, and Baidou, to name only few. Moreover, those devices will offer maybe 1TB storage capacity on-board, HD photography and HD video recording, allow for communication speeds of up to $1 \mathrm{GBit} / \mathrm{sec}$ using LTE/LAN/WLAN/WiFi, and have in service additional sensors, such as temperature, air pressure and pedometers. The devices will easily communicate (wirelessly) with large HD displays, and are therefore excellent tools for students of all education systems.
Learning has become and will be more pleasant as it was before. One may argue about the consequences of this unlimited use of mobile devices. However, this discussion will not lead to any useful outcome. As a matter of fact, most people will use mobile devices instead of desktop and notebook computers, especially the young generation. There are public opinions about the size of content currently taught in primary, secondary and higher education - it seems that the content offered the last 20-30 years is much too less nowadays and in future. We have to double, or may be, even to triple the content! How will we perform this mammoth task? The answer seems to be simple: use the most recent technology with all its pleasant gadgets and apps.

When Apple introduced the first iPod generation (2002) nobody could foresee the story of success of this mobile device. Today, close to 300 Million devices have been sold - the iTunes (Music) Store offers digital media content of all kind: music (MP3 and other formats), audio podcasts, video podcasts, TV series, movies, and e-Learning content (through the iTunes U extension). Last year, the iPhone $4 \mathrm{~S}$ ( $4^{\text {th }}$ generation iPhone) has been released, allowing for faster Internet access, HD photography, HD video capability, and other services. The iPad is a great success and is the leading device of tablet computing. The most recent iPad impresses with its high resolution display 
and quad core computing. Apple's app store offers more than 500.000 gadgets for download to make the iPad, iPhone or iPod Touch even more pleasant and powerful. The Apple TV allows for an easy link with the home theater TV, thus the iTunes Store comes to the couch when relaxing from a hard working day. Today, we find thousands of videos in the Apple podcast format (also in HD). Lesson learned: A computer manufacturer has become a world-wide leading institution for hardware, software and content!

Using the hype around iPod, iPhone and other mobile devices, learning content has to be offered in the same style and format as TV series, movies, YouTube videos, and others. Therefore, video podcasts (in short: vodcasts or videocasts) seem to be a de facto standard already. Many Higher Education (High Ed) institutions offer today vodcasts for their students (Fritsch, 2007). Starting the Apple iTunes U extension in USA (2006) it swapped to Europe 2008. This environment is Apple's answer to extend business and services to the $3 \mathrm{~L}$ community. Unlike radio or streaming content via the Web, vodcasts are not realtime. Vodcast material is pre-recorded and the users can check out the material on-line and off-line. Certain vodcasts can even be live and interactive - dozens of podcasts enthusiasts can be on at once, with the host being able to control the audience in the same way a radio host can.

The vision for the future is as follows: Vodcasts of all kind, especially for High Ed, are offered on the Web. The worldwide student (and 3L) community browses the Web and finds out the most brilliant vodcasts, according to their scientific content and pedagogical style. They rank these vodcasts just to give an indication about the quality and usability. Thus, it may happen easily, that preparations in GIS are made using database vodcasts of the Computer Science Dept. at MIT, visualization vodcasts of Univ. Stuttgart, analysis vodcasts of Tongji Univ. Shanghai, and data structure vodcasts of DIT. Student learning in High Ed becomes really international! Highly ranked vodcasts hide some potential for future business models in Life Long Learning (3L), which will be developed parallel to the more and more increasing vodcast offer.

Besides vodcasts there are many other initiatives, which complement traditional learning practices. Webinars seem to be another efficient method to offer elearning contents via the Web. Obviously this technology is used quite often by the geospatial industry to introduce new hardware, software and workflows to potential clients. Above all, it allows the end user to be far away from the original location of the seminar, and on the other hand the industry to present something good without renting rooms in hotels for presentations and accommodations, what finally means that both parties are saving money.

E-Learning platforms such as "Moodle" are also popular, especially for training purposes. The use of Moodle is simple and efficient - it allows for interactive teaching without any costs (Open Source) and has already a wide community. A comprehensive evaluation of several e-Learning platforms based on Open Source developments is given by Drewitz (2009).

\subsection{EuroSDR, a Pan European Body of Spatial R\&D}

EuroSDR is a European spatial data research organisation whose aim is to address the research needs of spatial data provision in Europe. With a current membership coming from seventeen European countries and a strong working relationship with related European organisations, EuroSDR has amassed considerable experience in addressing the extent and nature of this need.

Member organisations are diverse in nature with several only now tackling the provision of their national spatial data infrastructure (SDI), while others are at an advanced stage of implementation. EuroSDR is therefore anxious to facilitate the transfer of key knowledge and experience from those countries that have dealt successfully with the issues to those that are at a much earlier stage. This is one of the principle aims of the EduServ series of distance elearning courses, which, recently, has included topics related to SDI implementation such as 'Schema matching, mapping and transformation for INSPIRE', 'The INSPIRE Directive and its Implementing Rules' and 'Open Standards \& Open Source WebMapping'. Other courses have covered the complete spatial data provision cycle from data acquisition to maintenance and delivery of services. They are based on the results of collaborative applied research across Europe and represent the outcomes of shared activities, data, methods and experience. EuroSDR will publish its sixtieth official report in 2012.

\section{3 eLearning within EuroSDR by EduServ}

In order to facilitate the transfer of outcomes of EuroSDR research activities to the user domain, e.g. to key personnel in geographic information (GI) production organisations and industry, EuroSDR launched this annual series of elearning courses in 2002 and called it EduServ. The Internet courses are preceded by a seminar at which participants meet tutors and receive guidelines for following the courses from their own locations. Delivery of the two-week courses requires an acceptable level of Internet connectivity, which exists in most member countries. EuroSDR is aware, however, that should such courses be shared internationally, other forms of communication will need to be addressed, such as satellite broadcasting. This would require effective collaboration with related organisations with experience with this means of communication.

\section{EDUSERV@EUROSDR - A BRIEF HISTORY}

\subsection{Why EduServ?}

Publication of research and workshop reports is, in itself, not sufficient to attain the necessary goal of transferring the outcomes of EuroSDR research activities from the research to the user domain, in other words to key personnel in the GI production organisations and the user community. The impact of EuroSDR research is lessened if the results and outcomes are not translated into the GI production process (Heipke \& Mooney, 2009).

To address these concerns EuroSDR commenced its education service (EduServ) in October 2002, an annual series of short distance E-Learning courses based on specific research projects or on the recommendations of workshops (Mooney \& Stein, 2007)

The results of these research projects are learnt in depth with the goal that new technologies and methods are ultimately used by the national mapping agencies, private firms and universities of the member states. A EuroSDR task force organizes the educational service for each year. It selects the topics and the teachers of the courses. The teachers are recruited from the 
group of EuroSDR project leaders or from universities who have experience of the selected topic and E-Learning.

EduServ-10, the most recent module consisted of four two-week courses that ran consecutively from April to June 2012. Hosted by the Dublin Institute of Technology (DIT), Ireland, the courses attracted forty-two participants from twenty-seven organisations in seventeen countries.

Annual EduServ programmes consist of short (usually twoweek) consecutive Internet-delivered E-Learning courses, which are linked to the research activities of EuroSDR. They require approximately thirty hours of work (both online and offline) from the participants per course. Participants follow the courses remotely via the Internet either from their place of work or from home. On successful completion of all assignments and the submission of a detailed course evaluation feed back questionnaire, participants receive a signed 'Certificate of Completion' from EuroSDR.

Participants frequently have very different technical backgrounds. In most cases, they are professionals of European national mapping agencies, but some come from private firms as well as university students. E-Learning is unknown to many of the participants and cultural differences in the relationship between teacher and participant may exist. Therefore, the courses are preceded by a two-day seminar at which the participants meet with the course teachers and receive all necessary instruction and guidance to allow them follow the courses from their own organisations.

\subsection{EduServ Across Europe}

EduServ courses are offered in two successive years. During the courses, participants enjoy access to course tutors with a 24hour response to queries guaranteed. Thereafter, course material for these courses is made available online. EuroSDR continues to work with past course tutors to ensure that this valuable resource is maintained as an effective and sustainable archive.

So far, EduServ is organized at academic institutions (university institutes/departments) across Europe. Fortunately, EuroSDR is always finding volunteers from academia to organize the individual programs and courses without being charged. Precourse seminars and overall programme management have todate been hosted by nine different organisations (Table 1) and twenty courses delivered (Table 2).

\begin{tabular}{lll}
\hline Year & Host Organisation & Country \\
\hline 2002 & Aalborg University, Aalborg & Denmark \\
\hline 2004 & $\begin{array}{l}\text { Budapest University for } \\
\text { Technology and Economics, } \\
\text { Budapest }\end{array}$ & Hungary \\
\hline 2005 & $\begin{array}{l}\text { Dublin Institute of Technology, } \\
\text { Dublin }\end{array}$ & Ireland \\
\hline 2006 & ITC, Enschede & The Netherlands \\
\hline 2007 & Charles University, Prague & Czech Republic \\
\hline 2008 & $\begin{array}{l}\text { University of Applied Sciences, } \\
\text { Stuttgart }\end{array}$ & Germany \\
\hline 2009 & $\begin{array}{l}\text { Norwegian University of Life } \\
\text { Sciences, Ås }\end{array}$ & Norway \\
\hline 2010 & KU-Leuven, Leuven & Belgium \\
\hline 2011 & ENSG, Paris & France \\
\hline
\end{tabular}

$2012 \quad \begin{aligned} & \text { Dublin Institute of Technology, Ireland } \\ & \text { Dublin }\end{aligned}$

Table 1. EduServ Host Organisations (Vanden Berghe \& Mooney, 2011)

Details of the designers and teachers of these courses, together with the years in which they were included in EduServ programmes and the number of participants, are given in Table 2 .

\begin{tabular}{|c|c|c|c|}
\hline Course Title & Centre & Years & No.s \\
\hline $\begin{array}{l}\text { Integrated Sensor } \\
\text { Orientation }\end{array}$ & $\begin{array}{l}\text { University of } \\
\text { Hannover }\end{array}$ & $\begin{array}{l}2002 \\
2004\end{array}$ & $\begin{array}{l}14, \\
16\end{array}$ \\
\hline $\begin{array}{l}\text { Automatic Orientation of } \\
\text { Aerial Images on } \\
\text { Databases }\end{array}$ & $\begin{array}{l}\text { Aalborg } \\
\text { University }\end{array}$ & $\begin{array}{l}2002 \\
2004\end{array}$ & $\begin{array}{l}14, \\
18\end{array}$ \\
\hline $\begin{array}{l}\text { Laserscanning \& Airborne } \\
\text { Interferometric SAR }\end{array}$ & ITC, Enschede & $\begin{array}{l}2002 \\
2004\end{array}$ & $\begin{array}{l}14, \\
14\end{array}$ \\
\hline Digital Cameras/Sensors & $\begin{array}{l}\text { Ohio State } \\
\text { University }\end{array}$ & $\begin{array}{l}2004, \\
2005\end{array}$ & $\begin{array}{l}16, \\
15\end{array}$ \\
\hline $\begin{array}{l}\text { Co-ordinate Reference } \\
\text { Systems and } \\
\text { Transformations for Spatial } \\
\text { Data Position }\end{array}$ & $\begin{array}{l}\text { Dublin Institute } \\
\text { of Technology } \\
\text { (DIT) }\end{array}$ & $\begin{array}{l}2005 \\
2006\end{array}$ & $\begin{array}{l}12, \\
11\end{array}$ \\
\hline $\begin{array}{l}\text { Positional Accuracy } \\
\text { Improvement in GI } \\
\text { Databases }\end{array}$ & $\begin{array}{l}\text { Ordnance } \\
\text { Survey GB; TU- } \\
\text { Berlin; DIT } \\
\end{array}$ & $\begin{array}{l}2005 \\
2006\end{array}$ & $\begin{array}{l}13, \\
12\end{array}$ \\
\hline $\begin{array}{l}\text { Quality of Geospatial Data } \\
\text { and Related Statistical } \\
\text { Concepts }\end{array}$ & ITC, Enschede & $\begin{array}{l}2006, \\
2007\end{array}$ & $\begin{array}{l}15 \\
13\end{array}$ \\
\hline Quality Control of DTMs & $\begin{array}{l}\text { Aalborg } \\
\text { University }\end{array}$ & $\begin{array}{l}2006, \\
2007\end{array}$ & $\begin{array}{l}10, \\
21\end{array}$ \\
\hline Mapping with SAR & TU-Berlin & $\begin{array}{l}2007, \\
2008\end{array}$ & $\begin{array}{l}14, \\
18\end{array}$ \\
\hline $\begin{array}{l}\text { Laserscanning for 3D city } \\
\text { models }\end{array}$ & $\begin{array}{l}\text { Finnish } \\
\text { Geodetic } \\
\text { Institute } \\
\end{array}$ & $\begin{array}{l}2007 \\
2008\end{array}$ & $\begin{array}{l}18, \\
24\end{array}$ \\
\hline CityGML & $\begin{array}{l}\text { TU-Berlin and } \\
\text { University of } \\
\text { Gävle } \\
\end{array}$ & $\begin{array}{l}2008, \\
2009\end{array}$ & $\begin{array}{l}20, \\
11\end{array}$ \\
\hline $\begin{array}{l}\text { Geometric performance of } \\
\text { digital airborne cameras }\end{array}$ & $\begin{array}{l}\text { Institute for } \\
\text { Photogrammetry } \\
\text { (ifp), Stuttgart } \\
\text { University } \\
\end{array}$ & $\begin{array}{l}2008 \\
2009\end{array}$ & $\begin{array}{l}25 \\
15\end{array}$ \\
\hline $\begin{array}{l}\text { Schema matching, } \\
\text { mapping and } \\
\text { transformation for } \\
\text { INSPIRE }\end{array}$ & $\begin{array}{l}\text { University of } \\
\text { Gävle }\end{array}$ & $\begin{array}{l}2009 \\
2010\end{array}$ & $\begin{array}{l}9, \\
34\end{array}$ \\
\hline $\begin{array}{l}\text { Laserscanning for Tree } \\
\text { Extraction }\end{array}$ & $\begin{array}{l}\text { Finnish } \\
\text { Geodetic } \\
\text { Institute } \\
\end{array}$ & $\begin{array}{l}2009 \\
2010\end{array}$ & 9,9 \\
\hline $\begin{array}{l}\text { Assessment of the quality } \\
\text { of Digital Terrain Models }\end{array}$ & $\begin{array}{l}\text { Aalborg } \\
\text { University and } \\
\text { Charles } \\
\text { University } \\
\end{array}$ & $\begin{array}{l}2010 \\
2011\end{array}$ & $\begin{array}{l}12, \\
10\end{array}$ \\
\hline $\begin{array}{l}\text { The INSPIRE Directive } \\
\text { and its Implementing Rules }\end{array}$ & K.U.Leuven & $\begin{array}{l}2010, \\
2011\end{array}$ & $\begin{array}{l}22, \\
12\end{array}$ \\
\hline $\begin{array}{l}\text { Geodetic Reference } \\
\text { Systems }\end{array}$ & $\begin{array}{l}\text { IGN France / } \\
\text { LAREG }\end{array}$ & $\begin{array}{l}2011, \\
2012\end{array}$ & $\begin{array}{l}6 \\
10 \\
\end{array}$ \\
\hline 3D Urban Modelling & IGN France / & 2011 & 10 \\
\hline
\end{tabular}




\begin{tabular}{|c|c|c|c|}
\hline & MATIS & 2012 & 20 \\
\hline $\begin{array}{l}\text { Radiometric performance } \\
\text { of Digital Photogrammetric } \\
\text { Cameras and Laser } \\
\text { Scanners }\end{array}$ & $\begin{array}{l}\text { Finnish } \\
\text { Geodetic } \\
\text { Institute and } \\
\text { Vienna } \\
\text { University of } \\
\text { Technology }\end{array}$ & 2012 & 9 \\
\hline $\begin{array}{l}\text { Open Standards \& Open } \\
\text { Source WebMapping }\end{array}$ & $\begin{array}{l}\text { ITC - } \\
\text { University of } \\
\text { Twente }\end{array}$ & 2012 & 22 \\
\hline
\end{tabular}

Table 2. EduServ Courses, Centres, Years Delivered and Student Numbers (Vanden Berghe \& Mooney, 2011)

An evaluation of the effectiveness of EduServ courses is possible due to the requirement that participants must submit completed quality-assurance (QA) questionnaires prior to receiving their certificates. In general terms, participants have felt that the courses are useful, and most respondents indicate that the goals of the courses are achieved. Course material is appreciated and additional hardcopy material is found to be useful. The combination of the introductory seminar and ELearning was regarded as positive by about $70 \%$ of respondents and a similar percentage indicated that they would participate in further courses. Some participants have difficulties in keeping the time schedule and felt the work load was somewhat too heavy (more than 40 hours) and a small number considered the courses as difficult.

\section{LESSONS LEARNED FROM EDUSERV}

The experience of hosting ten EduServ modules so far suggests that such educational resources are of particular interest to the smaller states, both within and beyond Europe. This may be due in some part to the existence of adequate CPD resources in the larger states, which are not generally available in smaller ones. On the other hand, key staff members of GI organisations in several countries do not have high levels of proficiency in the English language and feel that such courses are beyond them.

\subsection{EduServ and Capacity Building}

This of course raises the issue of capacity building in general and in skills updating in particular in those European states where a comprehensive GI education resource does not exist but where the implications of European directives such as INSPIRE will require considerable training.

The EuroSDR EduServ model of distance E-Learning for CPD is an example of the use of appropriate technologies to assist states to build capacity but it must address the challenges of language and better marketing. There is also a need to be flexible and adaptive to new ways of learning, utilising state-ofthe-art solutions for communication and networking.

The pre-course seminar needs to be carefully designed and managed in order that participants benefit from attending in a way that justifies the considerable expense and disruption in taking time out of busy work situations and travelling to the seminar venue. It is all too easy to offer a series of stale presentations containing material that is, in fact, made available as part of the e-learning course. Future seminars should incorporate a significant degree of interactive discussion and identification of individual requirements.

\subsection{EduServ and Teach-the-Teacher Issues}

Since several instructors are scientists, some of them are new to e-learning from a tutoring perspective. The EduServ templates for organising e-learning courses are found to be very efficient in getting these instructors acquainted with this new way of learning. The templates consists of standardised procedures for course designs methods of delivering lectures, design of selfassessment tools etc. There is however no requirement that the instructor must follow these templates in detail. The course material and the didactic approach has to be designed with respect to the course content.

\section{CONCLUSIONS}

The experience of more than ten years of EduServ suggests that elearning courses are of particular interest to the smaller states within Europe. This may be due to the existence of adequate CPD (continuing professional development) resources in the larger states. However, key staff members of GI organisations in several countries may not have high levels of proficiency in the English language and, consequently, may feel that such courses are beyond them. Addressing the issue of capacity building and skills updating in those European states where a comprehensive GI education resource does not exist (but where considerable training in GI fields is still required) is seen by EuroSDR as a major challenge.

EuroSDR is also aware of the need to 'future proof' research capacity in all European states so that emerging GI research and education issues (in an increasingly 'joined-up' Europe) may be addressed effectively and economically. It is the firm intention of EuroSDR that its education service, EduServ, continues to address the issue of transferring the outcomes of its research activities to the GI production and user domain.

\section{References}

Drewitz, I. (2009). Evaluation of E-Learning Platforms. www.eworks.de.

Fritsch, D. (2007). Podcasting Photogrammetry - A Contribution to Life-Long Learning. In: Fritsch, D. (ed.), Photogrammetric Week '07, Wichmann, Heidelberg, pp. 335344.

Heipke, C., Mooney, K., 2009. EuroSDR - a Research Organisation Serving Europe's Geospatial Information Needs. In: Fritsch D. (ed.), Photogrammetric Week '09. Wichmann, Heidelberg, pp. 321-330.

Mooney, K., Stein, A. 2007. EduServ - The Education Service of EuroSDR - Building Capacity and Transferring Skills. In: Proceedings of INTED 2007 - International, Education and Development Conference, $7^{\text {th }}-9^{\text {th }}$ March 2007, Valencia, Spain.

Vanden Berghe, I., Mooney, K., 2011. EuroSDR e-learning courses for European Mapping Agencies. In: Hubeau, M., Steenberghen, T., Van Balen, K., Van Orshoven, J., Vileikis, O. (Eds), GIS-education in a changing academic environment, Proceedings of LeGIO-Workshop, Leuven, 18th of November, 2011

\section{Acknowledgements}

The authors would like to gratefully acknowledge the contributions of the lecturers of all EduServ programs in the past. Only with their spirit and efforts EduServ has become successful and visible in Europe and beyond. 